\title{
AEROBIC AND ANAEROBIC AMMONIUM OXIDISING BACTERIA ENRICHMENT FROM MINED MUNICIPAL SOLID WASTE IN SHARON- ANAMMOX PROCESS
}

\author{
Sri Shalini S. ${ }^{*}$, Kurian Joseph. \\ ${ }^{1}$ Centre for Environmental Studies, Anna University, Chennai-600025, India, \\ *E-mail: srishalini10@gmail.com (corresponding author)
}

\begin{abstract}
Ammoniacal nitrogen removal by novel processes like Single reactor system for high activity ammonia removal over nitrite (SHARON) and Anaerobic ammonium oxidation (ANAMMOX) processes are currently considered as advantageous than conventional processes. It requires aerobic ammonium oxidising bacteria (AOB) and anaerobic ammonium oxidising bacteria (AnAOB) to conduct the SHARON and ANAMMOX processes. This paper presents the feasibility of enriching the AOB and AnAOB using mined municipal solid waste (MSW) in batch reactors for a period of 37 days. In AOB reactor with nitrogen loading of $0.5 \mathrm{~kg} \mathrm{~N} / \mathrm{d}$ showed Partial Nitritation Efficiency of $82.6 \%$ with $3.8 \times 10^{8} \mathrm{MPN} / 100 \mathrm{~mL}$ of AOB population obtained. AnAOB reactor enriched with anammox biomass efficiently removed $78 \%$ of ammonia with the specific anammox activity reached up to $0.10 \mathrm{mg} \mathrm{NH}_{4}-\mathrm{N} / \mathrm{mg}$ MLVSS/d. The nitrogen transformations along with the formation of intermediates (hydrazine and hydroxylamine), biomass development, free ammonia and free nitrous acid concentrations in the batch reactors confirmed the enrichment AOB and AnAOB biomass activity using mined MSW.
\end{abstract}

(Keywords: Mined municipal solid waste, ammoniacal nitrogen removal, aerobic ammonium oxidising bacteria and anammox)

\section{INTRODUCTION}

Landfill is the most common method for the disposal of municipal solid waste (MSW) worldwide. $1-4 \%$ of MSW is Total Kjeldahl Nitrogen (TKN) composed of proteins. This nitrogen is getting accumulated as ammoniacal nitrogen in the landfill leachate by ammonification and solubilization [10]. Landfill leachate contains ammoniacal nitrogen concentration between 500$3000 \mathrm{mg} / \mathrm{L}$. Ammoniacal nitrogen has to be removed as it leads to algal growth, decreases performance of biological treatment systems, accelerates eutrophication, promotes oxygen depletion and increases aquatic toxicity [4]. Among the several biological processes for the removal of ammoniacal nitrogen, new innovative processes like SHARON (Single reactor system for high activity ammonia removal over nitrite) and ANAMMOX (Anaerobic ammonium oxidation) processes are being explored $[1,8,12]$.
It has several advantages than conventional processes like non addition of organic carbon, non production of $\mathrm{N}_{2} \mathrm{O}$, lower oxygen, alkalinity consumption, sludge production andinvestment /operational cost needed $[1,6]$.SHARON process is a partial nitrification process which oxidises half the influent ammonia to nitrite according to Equation 1, by aerobic ammonium oxidizing bacteria (AOB) $[8$, 12] such asNitrosomonas europaea, Nitrosomonas eutropha, Nitrosolobus sp, Nitrosopira $s p$ and Nitrosovibrio $s p$. [1, 18]. ANAMMOX process oxidises ammonia anaerobically using the nitrite as electron acceptor, produced in the SHARON process to nitrogen gas (Equation 2) by anaerobic ammonium oxidising bacteria (AnAOB) such as Candidatus Brocadia anammoxidans and Candidatus Kuenenia stuttgartiensis [5]. As, SHARON-ANAMMOX process has many benefits in terms of energy and resources, this process has been widely applied for removal of ammoniacal nitrogen from different ammonium rich wastewaters [16].

$$
\begin{gathered}
\mathrm{NH}_{4}+0.75 \mathrm{O}_{2}+\mathrm{HCO}_{3}^{-} \rightarrow 0.5 \mathrm{NO}_{2}^{-}+0.5 \mathrm{NH}_{4}^{+}+\mathrm{CO}_{2}+1.5 \mathrm{H}_{2} \mathrm{O} \\
\mathrm{NH}_{4}^{+}+1.32 \mathrm{NO}_{2}^{-}+0.066 \mathrm{HCO}_{3}^{-}+0.13 \mathrm{H}^{+} \rightarrow 1.02 \mathrm{~N}_{2}+0.26 \mathrm{NO}_{3}^{-}+0.066 \mathrm{CH}_{2} \mathrm{O}_{0.5} \mathrm{~N}_{0.15}+2.03 \mathrm{H}_{2} \mathrm{O}
\end{gathered}
$$


But, this process is limited by the low availability of AOB and AnAOB biomass. Commonly, enrichment of AOB and AnAOB biomass are carried out using seed source such as Activated sludge (for AOB) and
Nitrification sludge or Denitrification sludge or Anaerobic digestion sludge or/and Upflow anaerobic sludge blanket (for AnAOB)[18, 6, 9,22].

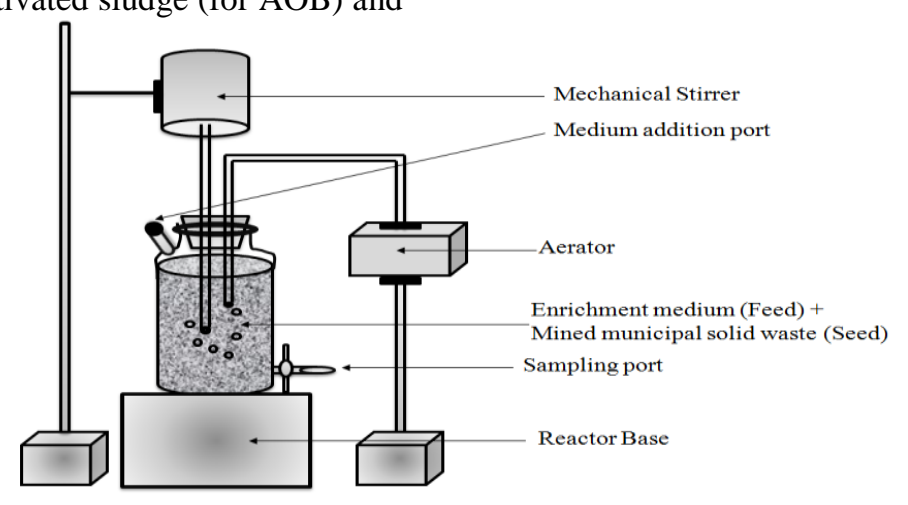

Figure 1. Schematic diagram of experimental set up for enrichment of AOB

Usage of mined municipal solid waste as seed for enriching AOB and AnAOB were not studied so far. The aim of this present study is to assess the feasibility for enriching the AOB and AnAOB biomass from mined MSW in batch reactors.

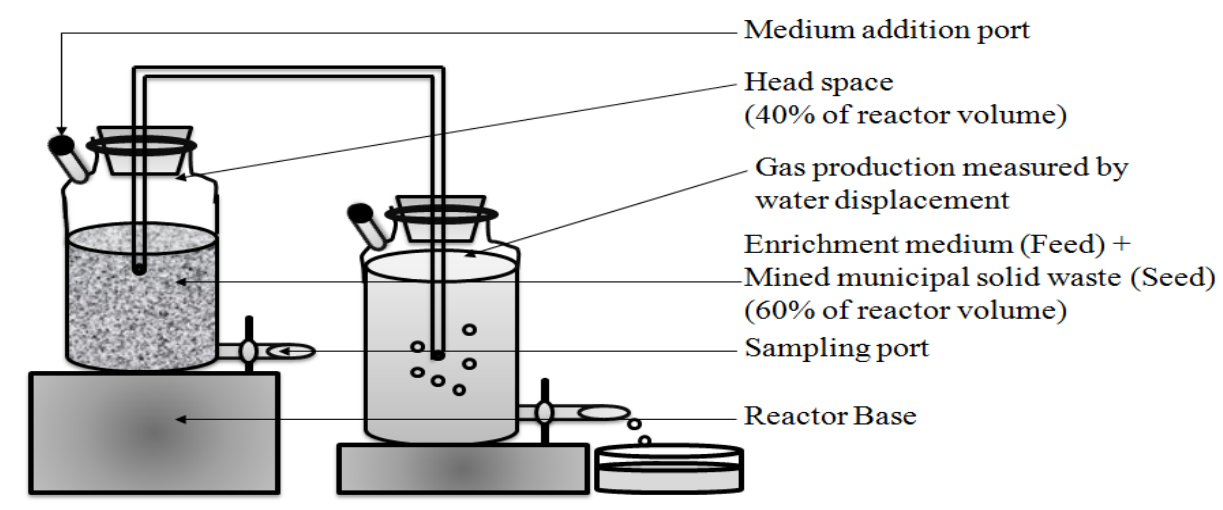

Figure 2. Schematic diagram of experimental set up for enrichment of AnAOBs

\section{MATERIAL AND METHODS}

\section{Characterisation of mined MSW}

Mined MSW samples (i.e. partially degraded MSW (three years old)) were augured manually from different locations of an MSW dumpsite in Chennai, India. Mined waste was used as seed for enriching AOB and AnAOB biomass. Mined MSW samples were analysed for moisture content (MC), total solids (TS), volatile solids (VS), organic carbon
(OC), ammoniacal nitrogen, nitrite and nitrate nitrogen was determined as per the standard methods [3].

\section{Experimental setup for enrichment of AOB and AnAOB in batch reactors}

Enrichment of AOB and AnAOB from mined MSW was carried out in two batch reactors namely, AOB and $\mathrm{AnAOB}$ reactor for 37 days as shown in Figure 1 and 2. The reactors were made up of borosilicate glass and run in duplicates. The reactors were 
started up using the AOB and anammox enrichment medium as feed which was as specifically described by [6] and [18]. Mined waste and enriched anammox biomass from a laboratory scale anammox reactor, Chennai was used as seed for AOB and AnAOB reactor, respectively. The enriched anammox biomass used was identified as Candidatus Brocadia anammoxidans based on the 16s rRNA sequencing analysis (Gene bank database: under accession number-JQ972060). The loading details of the reactors are summarised in the Table 1.

Table 1. Loading details of the batch reactors

\begin{tabular}{|c|c|c|c|}
\hline S.No & Parameters & $\begin{array}{c}\text { AOB reactor } \\
(\text { Enrichment of } \mathrm{AOB})\end{array}$ & $\begin{array}{c}\text { AnAOB reactor } \\
\text { (Enrichment of AnAOB) }\end{array}$ \\
\hline 1. & Reactor volume & $5 \mathrm{~L}$ & $2.5 \mathrm{~L}$ \\
\hline 2. & Feed/Seed ratio & $80 / 20$ & $60 / 40$ \\
\hline 3. & Feed & $4 \mathrm{~L}$ & $0.86 \mathrm{~L}$ \\
\hline 4. & Seed & $\begin{array}{l}831.8 \mathrm{~g} \text { of TS } \\
\text { (Mined waste) }\end{array}$ & $0.58 \mathrm{~L}$ (Enriched anammox biomass) \\
\hline 5. & Nutrients & $\mathrm{NH}_{4} \mathrm{HCO}_{3}-50 \mathrm{mM}$ & $\begin{array}{c}\mathrm{NH}_{4} \mathrm{SO}_{4}-1 \mathrm{mM} ; \mathrm{NaNO}_{2}-1 \mathrm{mM} \\
\mathrm{Na}_{2} \mathrm{SO}_{3}-0.01 \mathrm{mM}\end{array}$ \\
\hline
\end{tabular}

The experiment was carried out at ambient temperature. Complete mixing was achieved within the reactors by manual methods. In AOB reactor, aerators $(5 \mathrm{~L} / \mathrm{min})$ are used to maintain the dissolved oxygen level between $0.5-1.0 \mathrm{mg} / \mathrm{L}$. AnAOB reactor was covered with black cloth to avoid light interferences and anoxic condition was maintained by suffocation (i.e. cutting the supply of oxygen) method. Gas generation in the AnAOB reactor was monitored by water displacement method. $60 \%$ of the total AnAOB reactor volume was used as working volume and $40 \%$ as head space.

The reactors were operated in fed batch mode. Batch reactors were fed with enrichment medium for maintaining the working volume in the reactor, usually reduced during sampling and evaporation (especially, in AOB reactors). The quantity of samples $(25 \mathrm{~mL})$ withdrawn once in a week was replaced with the addition of enrichment medium without any nitrogen supplement. The samples were analysed every week for enrichment of AOB and AnAOB bacterial population. Nitrogen transformations were studied by analyses the content of ammoniacal nitrogen, nitrite and nitrate nitrogen as per the standard methods [3]. The AOB and anammox development was determined by trace appearance of intermediates such as hydrazine [20] and hydroxylamine [7] and bacterial biomass accumulation by MLVSS and MLSS analysis [3]. AnAOB activity was exhibited by Specific Anammox Activity (SAA).

The population of AOB was enumerated by Most Probable Number (MPN) were carried out for biomass samples from AOB reactors $[14,13]$. The medium used for MPN estimations for AOB contained, $0.5 \mathrm{~g}\left(\mathrm{NH}_{4}\right)_{2} \mathrm{SO}_{4} ; 0.2 \mathrm{~g} \mathrm{KH}_{2} \mathrm{PO}_{4} ; 0.2 \mathrm{~g}$ $\mathrm{MgSO}_{4} .7 \mathrm{H}_{2} 0 ; 0.02 \mathrm{~g} \mathrm{CaCI}_{2} .2 \mathrm{H}_{2} 0 ; 0.0075 \mathrm{~g}$ phenol red and $10 \mathrm{ml}$ trace elements, dissolved in a litre of distilled water. Trace elements solution contained $10 \mathrm{mg} \mathrm{NaMoO}{ }_{4} .2 \mathrm{H}_{2} 0 ; 20 \mathrm{mg} \mathrm{MnC}_{2} .4 \mathrm{H}_{2} 0 ; 0.2 \mathrm{mg}$ $\mathrm{CoCl}_{2} .6 \mathrm{H}_{2} \mathrm{0} ; 2 \mathrm{mg} \quad \mathrm{CuSO}_{4} .5 \mathrm{H}_{2} 0 ; 10 \mathrm{mg}$ $\mathrm{ZnSO}_{4} .7 \mathrm{H}_{2} \mathrm{O} ; 770 \mathrm{mg} \mathrm{FeSO} 4.7 \mathrm{H}_{2} 0$ and $1.03 \mathrm{~g} \mathrm{Na}-$ EDTA. pH of the medium was adjusted to 8.2 with $0.1 \mathrm{~N} \mathrm{NaOH}$ and $5 \mathrm{ml}$ of the medium were distributed into test tubes $(150 \mathrm{~mm} \times 15 \mathrm{~mm})$ which were then plugged and autoclaved at $121^{\circ} \mathrm{C}$ for 10 minutes. After sterilisation, $\mathrm{pH}$ dropped to 7.7 - 7.8.

Ten fold dilutions of biomass samples from AOB reactors were prepared in distilled water. Aliquots $(1 \mathrm{ml})$ of suitable dilutions were inoculated into test tubes containing medium and incubated at $37^{\circ} \mathrm{C}$. The growth of AOB in the medium was estimated at intervals of 1 or 2 weeks. Presence or absence of ammonium oxidising bacteria was monitored visually by observing whether the colour of the test medium remained pink (no growth) or turned 
yellow (growth) because of the decrease in $\mathrm{pH}$ resulting from the bacterial oxidation of ammonium. MPN was calculated depending upon the positive and negative tubes (Thomas formula).The nitrite accumulation rate in reactors was calculated by Partial Nitritation Efficiency (PNE) according to Liang and Liu [9] as given in the Equation 3.

where, $\quad \mathrm{C}_{\left(\mathrm{NO}_{2}-\mathrm{N}\right)_{\text {eff }}-\text { Concentrations of nitrite nitrogen in the effluent }(\mathrm{mg} / \mathrm{L})}$

Concentrations of free ammonia and free nitrous acid in the reactors were calculated according to the
Equation 4 and 5 suggested by Anthonisen et al. [17].

$$
\begin{aligned}
& \text { FA }\left(\mathrm{NH}_{3}, \mathrm{mg} / \mathrm{L}\right)=\frac{17 \times\left(\mathrm{NH}_{4}\right) \times 10^{\mathrm{pH}}}{14} \frac{\mathrm{e}^{(6344 /(273+\mathrm{t}))}+10^{\mathrm{pH}}}{\text { FNA }\left(\mathrm{HNO}_{2}, \mathrm{mg} / \mathrm{L}\right)=} \\
& \frac{46}{14} \times \frac{\left(\mathrm{NO}_{2}\right)}{\mathrm{e}^{(-2300 /(273+\mathrm{t}))} \times 10^{\mathrm{pH}}}
\end{aligned}
$$

Statistical analyses were carried out using statistical software package SPSS (version 20.0) for Windows (SPSS, USA). The replicability of the batch reactors were validated by Pearson's correlation analysis. Correlation results are statistically significant when significance coefficient is smaller than $0.05(\mathrm{P}<$ $0.05)$.

\section{RESULTS AND DISCUSSION}

\section{Seed characteristics}

Mined waste was used as seed for enrichment of AOB and AnAOB. The physico-chemical characteristics of the mined waste showed moisture content with $20.8 \%$ and had sufficient solids concentration of $79.2 \%$ with $13.3 \%$ of volatile solids. The total organic carbon was around $5 \%$. Nitrogen load in the waste was ammoniacal nitrogen: $0.5 \mathrm{~kg} \mathrm{~N} / \mathrm{d}$, nitrite nitrogen: $0.01 \mathrm{~kg} \mathrm{~N} / \mathrm{d}$ and nitrate nitrogen: $0.03 \mathrm{~kg} \mathrm{~N} / \mathrm{d}$. The enriched anammox biomass from a laboratory scale anammox reactor, Chennai was used as seed for anammox reactor. Inorganic nitrogen load was $0.041 \mathrm{~kg} \mathrm{~N} / \mathrm{d}$ (ammoniacal nitrogen: $0.02 \mathrm{~kg} \mathrm{~N} / \mathrm{d}$, nitrite nitrogen: $0.001 \mathrm{~kg} \mathrm{~N} / \mathrm{d}$ and nitrate nitrogen:
$0.02 \mathrm{~kg} \mathrm{~N} / \mathrm{d}$ ). The biomass concentration of the anammox seed was $36.4 \mathrm{~g} / \mathrm{kg}$ of suspended solids.

\section{Enrichment of Aerobic Ammonium Oxidising Bacteria $(\mathrm{AOB})$ in batch reactors}

The enrichment of AOBs was conducted in 5L reactors with mined waste as seed. The aim of the study was to enrich AOB using mined MSW in the reactors by inhibiting the growth of Nitrite oxidising bacteria (NOB). NOBs are the main competitor for AOBs in substrate utilisation, if they are inhibited, AOB can build up faster and nitrite accumulation takes place [11]. The important operational parameters for AOBs to grow require optimum $\mathrm{pH}$, temperature and DO. $\mathrm{pH}$ of the reactors were in the range of $7.6-8.2$, DO: $0.5-1 \mathrm{mg} / \mathrm{L}$ and temp: $30-$ $30.6^{\circ} \mathrm{C}$, indicated the favourable conditions existed in the reactors for the AOBs to grow [8, 6, 14]. According to Paredes et al. [11], at temperatures greater than $15^{\circ} \mathrm{C}$ AOBs can grow faster than NOBs and around $25^{\circ} \mathrm{C}$, the $\mathrm{AOB}$ can outcompete NOB. The conductivity and salinity of the reactors was 9.7 to $12.3 \mathrm{mS} / \mathrm{cm}$ and 6.2 to $8.1 \mathrm{psu}$, respectively. 
Nitrogen transformations along with the Partial nitritation efficiency during the enrichment of AOBs in reactors are depicted in the Figure 3. The peak ammonia concentration in the reactor was $543.2 \mathrm{mg} / \mathrm{L}$ and $50 \%$ removal of ammonia was reached within 30 days achieving to $\mathrm{NO}_{2}-\mathrm{N} / \mathrm{NH}_{4}-\mathrm{N}$ ratio of $1: 1$. The nitrite concentration elevated up to $316 \mathrm{mg} / \mathrm{L}$, whereas nitrate level never exceeded 67 $\mathrm{mg} / \mathrm{L}$ in the reactors. The nitrite accumulation rate is an indication of the activity of $\mathrm{AOBs}$, as the rate increases it shows that the activity of AOBs are more. Partial nitritation efficiency (nitrite accumulation rate) enhanced from 25.6 to $82.6 \%$ in the reactors during the study period demonstrated the AOB activity.

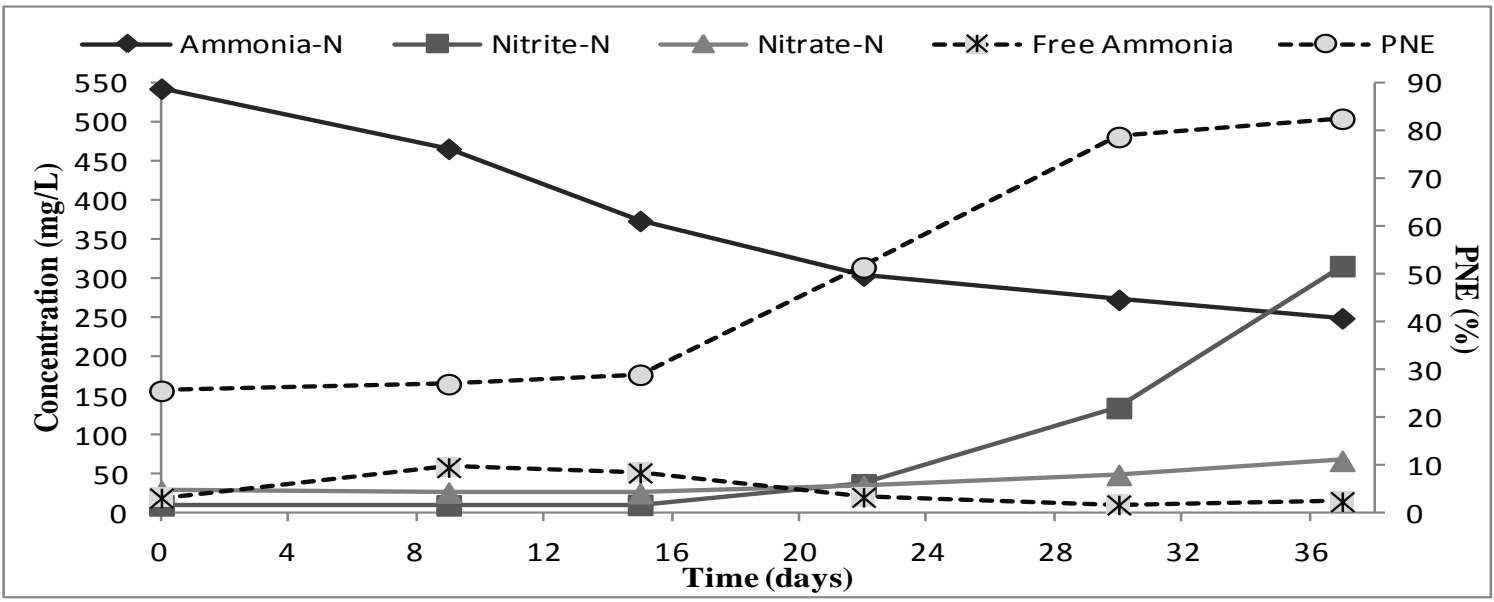

Figure 3. Nitrogen transformations in the batch reactors during the enrichment of AOBs

FA concentrations in the reactors were above 0.1 $\mathrm{mg} / \mathrm{L}$ throughout the study, which is an inhibitory value for NOBs [2] (Figure 3). The peak free ammonia concentration was only $58 \mathrm{mg} / \mathrm{L}$ and never reached the inhibitory value $(150 \mathrm{mg} / \mathrm{L})$ for AOBs. FNA concentrations maximum reached in the reactors was $0.034 \mathrm{mg} / \mathrm{L}$ (Figure 4) which was not an inhibitory range for AOBs and NOBs (0.2 $\mathrm{mg} / \mathrm{L})[2]$. Hence, NOBs are mainly inhibited due to free ammonia and not due to free nitrous acid concentrations in the reactors.

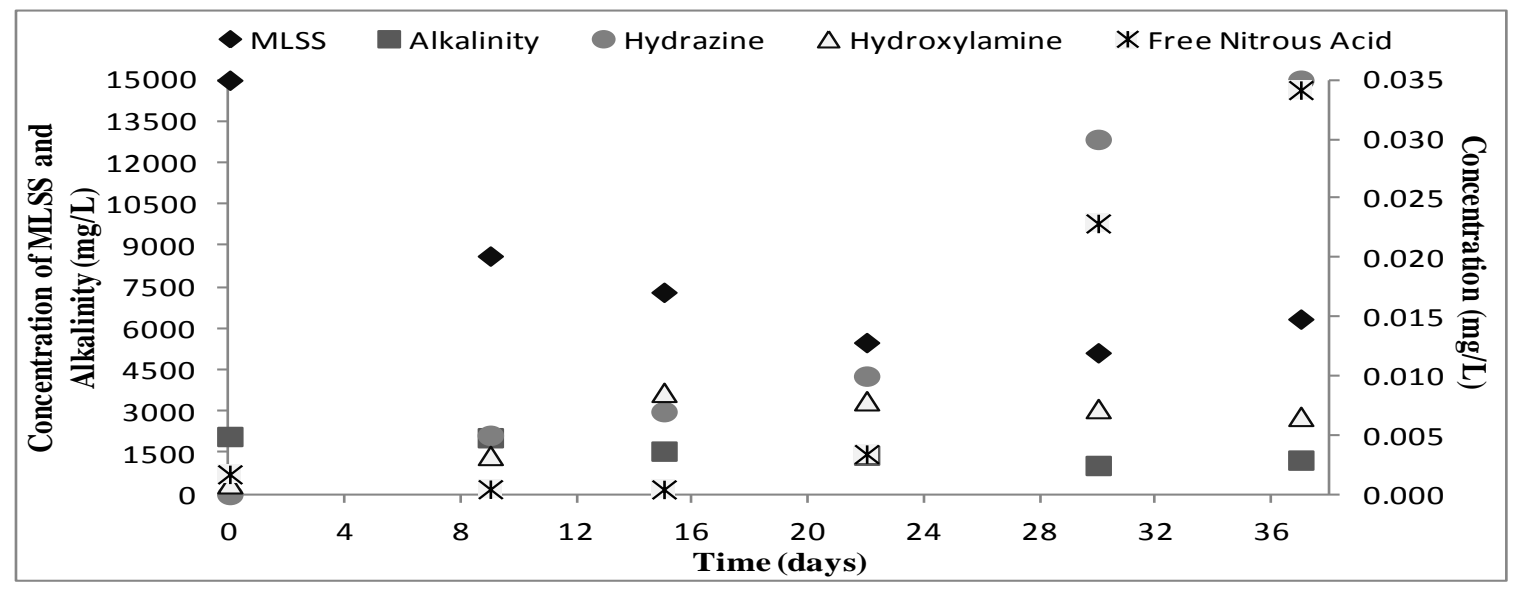

Figure 4. Performance of the batch reactors during the enrichment of AOBs 
Availability of bicarbonates (alkalinity) is essential for AOBs, as the conversion of ammonia to nitrite is an acidifying process neutralised by bicarbonates [8]. Figure 4 showed adequate amount of bicarbonates were available in the reactors for $\mathrm{AOB}$ organisms to grow which was substantiated by biomass development. Biomass was measured by MLSS concentrations. Initially, MLSS concentration was $15,000 \mathrm{mg} / \mathrm{L}$ and reached to 6350 $\mathrm{mg} / \mathrm{L}$ during the study period exhibited that under optimum reactor conditions only AOBs were developed. AOBs activity was confirmed by the occurrence of hydroxylamine and hydrazine concentrations in the reactors (Figure 4). Accumulation of intermediates was observed within a week in the reactors. The range of hydroxylamine and hydrazine was 0.001 to $0.010 \mathrm{mg} / \mathrm{L}$ and 0.005 to $0.035 \mathrm{mg} / \mathrm{L}$, respectively [12]. Further, the confirmation of AOB bacterial population was investigated by conducting the MPN analysis specific for AOB [14, 13]. MPN obtained for the reactor biomass sample were $3.8 \times 10^{8} \mathrm{MPN} / 100 \mathrm{~mL}$, illustrated the adequate quantity of $\mathrm{AOB}$ population existed in the reactor. The results authenticated that ample concentrations of intermediates with biomass development and AOB specific MPN population acquired in the batch reactors established the enrichment of AOBs. The replicability of the experiment was validated by Pearson's correlation analysis showed significantly strong correlation with $85-95 \%$ in the reactors.

\section{Enrichment of Anaerobic Ammonium Oxidising Bacteria (AnAOB) in batch reactors}

The anammox bacterial enrichment was observed in terms of operational parameters $(\mathrm{pH}$, temperature), nitrogen transformations, biomass development and presence of trace amounts of intermediates $[5,18] . \mathrm{pH}$ and temperature of the AnAOB reactors was $7.3-8.4$ and $30-32^{\circ} \mathrm{C}$, demonstrating that the reactors were under optimum conditions for the anammox bacterial growth in the reactors [21]. The conductivity and salinity of the reactors was 2.7 to $3.0 \mathrm{mS} / \mathrm{cm}$ and $1.4-1.7 \mathrm{psu}$, respectively.

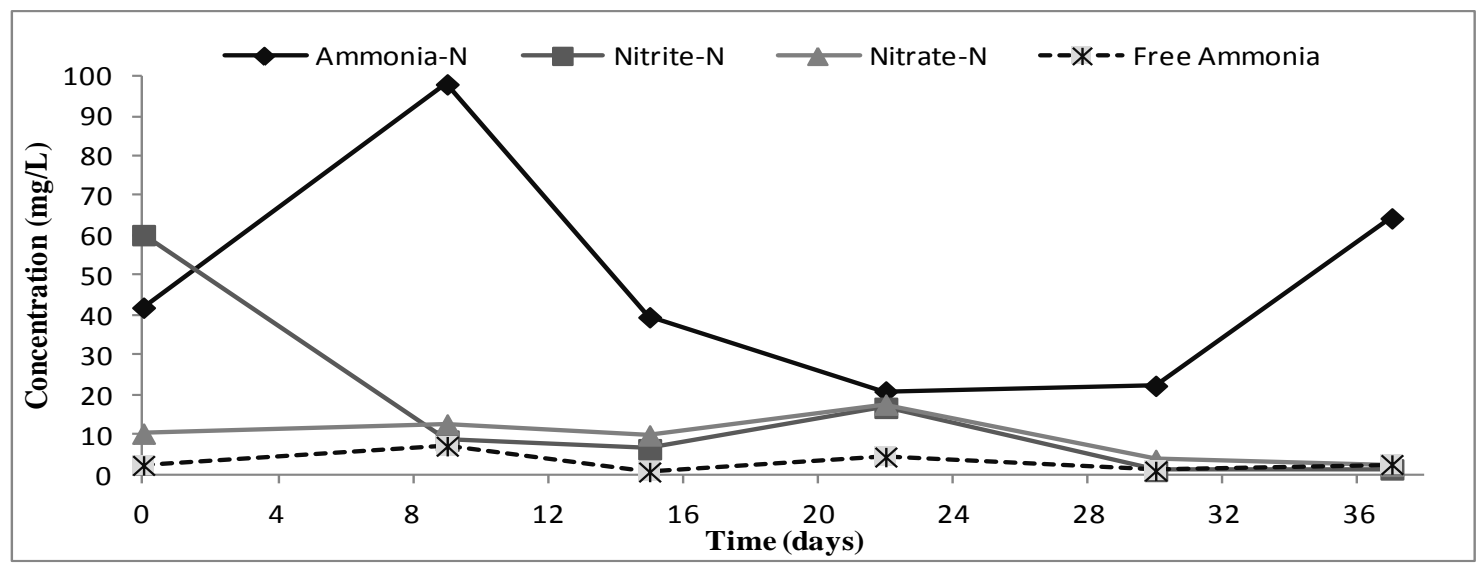

Figure 5. Nitrogen transformations in the batch reactors during the enrichment of AnAOBs

Nitrogen transformations during the enrichment of AnAOBs in the reactors are depicted in the Figure 5. The maximum level of ammonia concentration was $98 \mathrm{mg} / \mathrm{L}$ reached within a week and ammonia removal efficiency increased up to $78 \%$ during the end of the study period. Simultaneous reduction in the nitrite concentration from 60.2 to $1.5 \mathrm{mg} / \mathrm{L}$ in 37 days demonstrated the growth of anammox bacteria with the consumption of nitrite as electron acceptor. Concentrations of nitrate prevailed in the reactor was in the range of 2.3 to $17.7 \mathrm{mg} / \mathrm{L}$. Nitrate production illustrated that the nitrite converted to nitrate for producing the reducing equivalents for $\mathrm{CO}_{2}$ fixation in anammox process [17]. The presence of nitrite and nitrate concentrations in the reactors also revealed existence of AOBs and NOBs along with the anammox bacteria. Free ammonia and free nitrous acid concentrations in the reactors are depicted in the Figure 5 and 6. FA concentrations in the reactors were above $0.1 \mathrm{mg} / \mathrm{L}$ showed NOBs are inhibited. Free nitrous acid concentrations in the reactors elevated to $0.007 \mathrm{mg} / \mathrm{L}$ and never reached the inhibitory value of $0.2 \mathrm{mg} / \mathrm{L}$ in the study period [2]. 


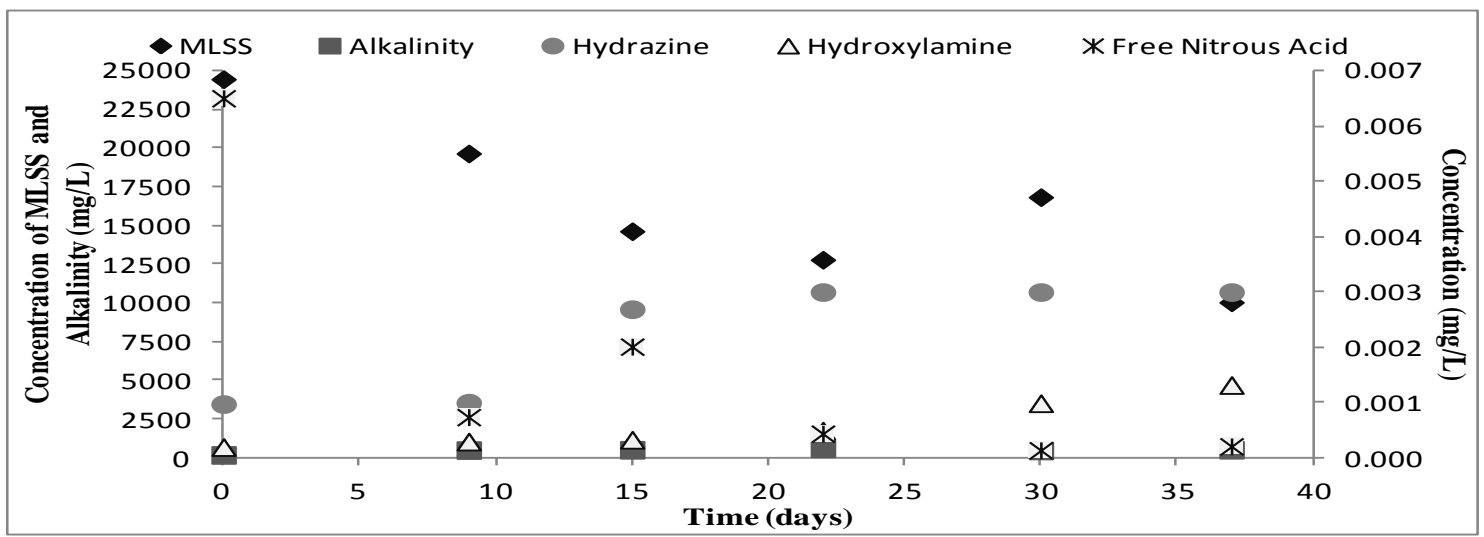

Figure 6. Performance of the batch reactors during the enrichment of AnAOBs

Alkalinity can be used as the indicator parameter for the anammox activity, as anammox bacteria consumes bicarbonate as their carbon source [21]. Variations in the bicarbonate concentrations in the reactors are depicted in the Figure 6. As sufficient bicarbonates were available in the reactor, the nitrogen removal by anammox process was increased. The anammox development in the reactor can be demonstrated by the Specific anammox activity. Initially, SAA was $0.005 \mathrm{mg} \mathrm{NH}-\mathrm{N} / \mathrm{mg}$ MLVSS/d and in 37 days of reactor operation it reached to $0.10 \mathrm{mg} \mathrm{NH}_{4}-\mathrm{N} / \mathrm{mg}$ MLVSS/d, which is comparable with the outcomes of the study conducted by Wang et al. [19].

The colour of the biomass in the reactor was also changed from black colour to brownish colour in the end of the study period due to the development of anammox bacteria. The biomass growth with the occurrence of trace concentrations of hydrazine and hydroxylamine authenticated the AnAOB enrichment (Figure 6). The hydrazine concentration was in the range of 0.001 to $0.003 \mathrm{mg} / \mathrm{L}$ and hydroxylamine was around 0.0002 to $0.001 \mathrm{mg} / \mathrm{L}$ in the reactors. The trace occurrences of intermediates (hydrazine and hydroxylamine) with the specific anammox activity proved the enrichment of AnAOB [15]. The reactors are validated by the duplicate reactors, which gave $90-95 \%$ correlation.

\section{CONCLUSION}

The study confirmed the feasibility for using mined MSW as seed for enriching the aerobic and anaerobic ammonium-oxidising bacteria in batch reactors. The enrichment of $\mathrm{AOB}$ and $\mathrm{AnAOB}$ operated for 37 days with nitrogen loading of 0.5 $\mathrm{kg} / \mathrm{N} / \mathrm{d}$ was authenticated by nitrogen transformation profiles, biomass accumulation, alkalinity, FA, FNA concentrations and occurrences of intermediates such as hydrazine and hydroxylamine in the reactors. Further, AOB activity was validated by $82.6 \%$ of Partial Nitritation Efficiency with AOB populations of 3.8 $\times 10^{8} \mathrm{MPN} / 100 \mathrm{~mL}$ and AnAOB activity by $78 \%$ removal of ammoniacal nitrogen with specific anammox activity of $0.10 \mathrm{mg} \quad \mathrm{NH}_{4}-\mathrm{N} / \mathrm{mg}$ MLVSS/d.

\section{ACKNOWLEDGEMENT}

The support of the All India Council for Technical Education to carry out this study in the form of National Doctoral Fellowship to the corresponding author is gratefully acknowledged.

\section{REFERENCES}

1. Ahn Y.H. (2006). Sustainable nitrogen elimination biotechnologies: A review. Process Biochem. 41: 1709-1721.

2. Anthonisen A. C., Loehr R. C., Prakasam T. B. S. and Srinath E. G. (1976). Inhibition of nitrification by ammonia and nitrous acid. J. WPCF 46: 835-852.

3. APHA (1998) Standard Methods for the Examination of Water and Wastewater. 20th edn. United Book Press, USA.

4. Berge N. D., Reinhart D. R. and Townsend T. G. (2005). The fate of Nitrogen in Bioreactor landfills. Crit. Rev. Environ. Sci. Technol. 35: 365-399. 
5. Dapena-Mora A., Campos J. L., Mosquerra-Corral A., Jetten M. S. M. and Mendez R. (2004). Stability of the ANAMMOX process in a gas - lift reactor and a SBR. J. Biotechnol. 110: 159-170.

6. Egli K., Langer C., Siegrist H-R., Zehnder A. J. B., Wagner M. and van der Meer J. R. (2003). Community analysis of Ammonia and nitrite oxidisers during start-up of nitritation reactors. Appl. and Environ. Microbiol. 69: 3213-3222.

7. Frear D. S. and Burrell R. C. (1955). Spectrophotometric Method for Determining Hydroxylamine Reductase Activity in Higher Plants. Anal. Chem. 27: 1664-1665.

8. Ganigue R., Gabarro J., Sanchez-Melsio A., Ruscalleda M., Lopez H., Vila X., Colprim J. and Balaguer M.D. (2009). Long-term operation of a partial pilot plant treating leachate with extreme high ammonium concentration prior to an anammox process. Bioresour. Technol. 100: 5624-5632.

9. Liang Z. and Liu J. X. (2007). Control factors of partial nitritation for landfill leachate treatment. J. Environ. Sci. (China) 19: 523-529.

10. Onay T.T. and Pohland F.G. (1998). In situ nitrogen management in controlled bioreactor landfills. J. Water Res. 32: 1383-1392.

11. Paredes D., Kuschk P., Mbwette T. S. A., Stange F., Muller R. A. and Koser H. (2007). New aspects of microbial nitrogen transformations in the context of waste water treatment - A review. Eng. Life Sci. 7: $13-25$.

12. Peng B. and Zhu G. (2006). Biological nitrogen removal with nitrification and denitrification via nitrite pathway. Appl. Microbiol. Biotechnol. 73: 15-26.

13. Philips S. and Verstraete W. (2001). Effect of repeated addition of nitrite to semi-continuous activated sludge reactors. Bioresour. Technol. 80: 73-82.

14. Sarathchandra S.U. (1979). A simplified method for estimating ammonium oxidising bacteria. Plant and Soil 52: 305309.

15. Shivaraman N. and Geetha S. (2003). Anammox - A novel microbial process for ammonium removal. Current Science 84: 1507-1508.

16. Sri Shalini S. and Kurian Joseph. (2012). Nitrogen management in landfill leachate: Application of SHARON, Anammox and combined SHARON-ANAMMOX process. Waste Management 32: 23852400.

17. Strous S., Heijnen J. J., Kuenen J. G. and Jetten M. S. M. (1998). The sequencing batch reactor as a powerful tool for the study of slowly growing anaerobic ammonium-oxidising microorganisms. Appl. Microbiol. Biotechnol. 50: 598-596.

18. Van de graaf A. A., Bruijn P. D., Robertson L. A., Jetten M. S. M. and Kuenen J. G. (1996). Autotrophic growth of anaerobic ammonium oxidizing microorganisms in a fluidized bed reactor. Microbiol. 142: 2187-2196.

19. Wang T., Zhang H., Yang F., Liu S., Fu Z. And Chen H. (2009). Start up of the ANAMMOX process from the conventional activated sludge in a membrane bioreactor. Bioresour. Technol. 100: 2501-2506.

20. Watt G. W. and Chrisp J. D. (1952). A Spectrophotometric Method for the Determination of Hydrazine. Anal. Chem. 24: 2006-2008.

21. Zhang H. and Zhou S. (2006). Treating leachate mixture with anaerobic ammonium oxidation technology. $J$. Central South Univ. Technol. 13: 663-667.

22. Zhang L., Zheng P., Tang C. and Jin R. (2008). Anaerobic ammonium oxidation for treatment of ammonium-rich wastewaters. J. Zhejiang Univ. SCI B 9: 416-426. 